\title{
Perbedaan Daya Hambat Ekstrak Daun Sirih Hijau ( Piper betle L. ) dan Daun Sirih Merah ( Piper crocatum Ruiz \& Pav ) terhadap Pertumbuhan Escherichia coli
}

\author{
Tristika Aulia Syahrinastiti ${ }^{1}$,Aziz Djamal ${ }^{2}$, Lili Irawati $^{3}$
}

\begin{abstract}
Abstrak
Sirih hijau (Piper betle L.) dan sirih merah (Piper crocatum Ruiz \& Pav) dipercaya memiliki khasiat mencegah penyakit infeksi saluran kemih yang disebabkan oleh Escherichia coli. Tujuan penelitian ini adalah untuk menjelaskan perbedaan daya hambat ekstrak daun sirih hijaudan daun sirih merah terhadap pertumbuhan Escherichia coli. Jenis penelitian ini adalah eksperimental dengan desain post test only control group. Penelitian dilakukan di laboratorium mikrobiologi Fakultas Kedokteran Universitas Andalas. Hasil penelitian adalah: 1. Efek daya hambat ekstrak daun sirih merah pada konsentrasi 2,5\%,5\%,7,5\%, dan 10\%, yaitu 0,6cm, 1,1 cm, 1,2cm, dan 1,2cm; 2. Ekstrak daun sirih hijau tidak memiliki efek daya hambat pada konsentrasi 2,5\%,5\%,7,5\%, dan $10 \%$. Kesimpulan eksperimen ini adalah ekstrak daun sirih merah memiliki efek daya hambat lebih baik daripada ekstrak daun sirih hijau.
\end{abstract}

Kata kunci: ekstrak daun sirih hijau, ekstrak daun sirih merah, escherichia coli, daerah bebas hambat

\begin{abstract}
Green betel (Piper betle L.) and red betel (Piper crocatum Ruiz \& Pav) are trusted of possessing an efficacy of preventing urinary tract infection caused by Eschericia coli. The objective of this study was to explain the difference of inhibition zones between the green betel and the red betel towards the growth of Eschericia coli. The type of this research was experimental study with post test only control group design. This research was carried out in Microbiology Laboratory, Faculty of Medicine Andalas University. The results of this research were: 1.The inhibition zones of red betel extract in concentration of 2.5\%,5\%,7.5\%, and 10\% were $0.6 \mathrm{~cm}, 1.1 \mathrm{~cm}, 1.2 \mathrm{~cm}$, and $1.2 \mathrm{~cm} ; 2$. The extract of green betel had none of inhibition zones in concentration of of $2.5 \%, 5 \%, 7.5 \%$, and $10 \%$. In conclusion, the red betel extract has better inhibition zones than the green betel extrac.
\end{abstract}

Keywords: green betel extract, red betel extract, eschericia coli, inhibition zone

Affiliasi penulis : 1. Pendidikan Dokter FK UNAND (Fakultas Kedokteran Universitas Andalas Padang), 2. Bagian Mikrobiologi FK UNAND/RSUP Dr. M. Djamil, 3. Bagian Fisika FK UNAND/RSUP Dr. M. Djamil

Korespondensi : Tristika Aulia Syahrinastiti,

E-mail:tristikaaulia@gmail.com, telp :082129927780

\section{PENDAHULUAN}

Salah satu tanaman obat yang dikenal oleh masyarakat awam adalah sirih hijau (Piper betle $L$ ) yang termasuk dalam kelompok tanaman obat yang mencapai lebih dari 1000 jenis. Terdapat berbagai macam jenis sirih hijau yaitu sirih hijau, sirih merah. Sirih hijau sering digunakan untuk mengatasi bau badan dan mulut, sariawan mimisan, gatal-gatal dan koreng, serta mengobati keputihan pada wanita. Selain sirih hijau, salah satu jenis sirih hijau lainnya yang saat ini banyak digunakan untuk kesehatan ialah sirih merah. Walaupun kandungan kimia tanaman ini belum diteliti secara detail, hasil krematoGram daun sirih merah mengandung flavonoid, senyawa polevenolad, tanin dan minyak atsiri. Senyawa tersebut yang diyakini dapat mengobati berbagai penyakit. $^{1}$

Kandungan fenol yang terkandung dalam sirih hijau diyakini memiliki kandungan lebih banyak dibanding fenol pada umumnya. Fenol dapat 
menghambat aktivitas bakteri. Salah satu cara menghambat pertumbuhan bakteri ialah dengan cara menghambat proses pembentukan dinding sel atau dengan melisiskan dinding sel yang sudah terbentuk. Namun, mekanisme antibakteri pada proses penghambatan pertumbuhan bakteri dari ekstrak daun sirih hijau masih perlu diteliti.

Pada penelitian Suliantari di tahun 2008, ekstrak daun sirih hijau yang diperoleh dengan pelarut etanol mempunyai aktivitas antibakteri terhadap beberapa bakteri Gram positif dan Gram negatif yang salah satunya adalah Escherichia coli, yang hasilnya pelarut etanol dapat menghambat pertumbuhan sebesar $14 \mathrm{~mm}$ dan untuk konsenterasi minimum penghambatan (Minimum Inhibitory Concentracion) didapatkan sebesar $1 \% .{ }^{1}$ Pengaruh ekstrak daun sirih hijau (Piper betle L.) terhadap pertumbuhan Escherichia coli dengan metode difusi disk didapatkan pada konsentrasi 2,5\%,5\% dan $10 \%$ dengan daya hambat sebesar 10,00; 9,420; dan 10,57 mm. ${ }^{2}$

Pada penelitian yang dilakukan dengan menggunakan ekstrak sirih merah (Piper crocatum Ruiz \& Pav) dengan pelarut etanol secara standar dapat menghambat dan membunuh Escherichia coli pada konsentrasi $6,25 \%$, di lain penelitian dengan metode dilusi cair didapatkan konsentrasi sekitar 0,5\%. Sedangkan, pada ekstrak etanol $80 \%$ dari sirih merah pada konsentrasi $2,5 \%, 5 \%, 7,5 \%$ dan $10 \%$ didapatkan daya hambat pada Escherichia coli sebesar 14,3 mm; 15,6 mm; 17 mm;19 mm. ${ }^{3-5}$

Escherichia coli merupakan kuman oportunis yang normal ditemukan dalam usus besar manusia. Sifatnya yang unik, bakteri Escherichia coli dapat menyebabkan infeksi primer. Bakteri ini bersifat patogen apabila berada di luar usus, yaitu lokasi normal tempatnya berada atau di lokasi lain di mana flora normal jarang terdapat. Tempat yang paling sering terkena infeksi yang paling penting secara klinik adalah saluran kemih, saluran empedu, dan tempattempat lain di rongga perut, kemudian ketika ketahanan tubuh inang tidak adekuat dapat menimbulkan infeksi lokal yang secara klinik dapat mencapai aliran darah lalu menimbulkan sepsis.

Escherichia coli adalah penyebab yang paling lazim dari infeksi kandung kemih dan merupakan penyebab infeksi saluran kemih pertama pada kira-kira
90\% wanita muda dan penyebab diare yang utama. Penyakit diare termasuk dalam 10 penyakit yang sering menimbulkan kejadian luar biasa. Berdasarkan laporan Surveilans Terpadu Penyakit bersumber data KLB (STP KLB) tahun 2010, diare menempati urutan ke-6 frekuensi KLB terbanyak setelah DBD, Chikungunya, Keracunan makanan, Difteri dan Campak. $^{6}$

Berdasarkan uraian diatas, maka perlu dilakukan penelitian ini tentang uji kadar hambat daun sirih hijau (Piper betle L.) dan daun sirih merah (Piper crocatum Ruiz \& Pav Ruiz) terhadap pertumbuhan Escherichia coli dengan menggunakan metode ekstraksi sederhana (maserasi) dan dengan penggunaan kadar etanol yang lebih tinggi, 96\% untuk melihat ada tidaknya perbedaan

\section{METODE}

Penelitian ini bersifat eksperimental post test only control group design. Populasi adalah dua jenis daun sirih yang ada di Padang. Sampel adalah daun sirih (Piper betle $I$ ) dan daun sirih merah (Piper crocatum Ruiz \& Pav). Sampel diambil dengan menggunakan metode Purposive Sampling, yaitu menentukan ekstrak daun sirih dan daun sirih merah dengan konsentrasi 2,5\%,5\%,7,5\% dan $10 \%$

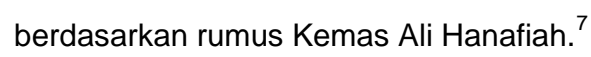

[ $(\mathrm{t}-1)(\mathrm{r}-1) \geq 15]$; $\mathrm{t}=$ perlakuan (konsentrasi), $\mathrm{r}=$ ulangan.

Dari rumus diatas diperlukan pengulangan sebanyak 6 kali sehingga didapatkan 24 sampel.

\section{HASIL}

Tabel 1. Hasil diameter daerah bebas pertumbuhan Escherichia coli (ekstrak daun sirih hijau)

\begin{tabular}{ccccccccc}
\hline No. & $\begin{array}{c}\text { Konsentrasi } \\
\text { Ekstrak daun } \\
\text { Sirih Hijau }\end{array}$ & \multicolumn{1}{c}{ Pengulangan } & $\begin{array}{c}\text { Rerata } \\
\text { (cm) }\end{array}$ \\
\hline & & I & II & III & IV & V & VI & \\
1 & $2,5 \%$ & 0 & 0 & 0 & 0 & 0 & 0 & 0 \\
2 & $5 \%$ & 0 & 0 & 0 & 0 & 0 & 0 & 0 \\
3 & $7,5 \%$ & 0 & 0 & 0 & 0 & 0 & 0 & 0 \\
4 & $10 \%$ & 0 & 0 & 0 & 0 & 0 & 0 & 0 \\
\hline
\end{tabular}

Tabel pengujian 1 dan 2 memperlihatkan adanya perbedaan daya hambat antara ekstrak daun sirih hijau dan ekstrak daun sirih merah pada empat 
konsentrasi. Ekstrak daun sirih merah memiliki daya hambat yang lebih baik dibandingkan dengan ekstrak daun sirih hijau.Semakin tingginya konsentrasi juga memberikan daya hambat yang lebih besar seperti yang dapat dilihat pada Tabel 2.

Tabel 2. Hasil diameter daerah bebas pertumbuhan Escherichia coli (ekstrak daun sirih merah).

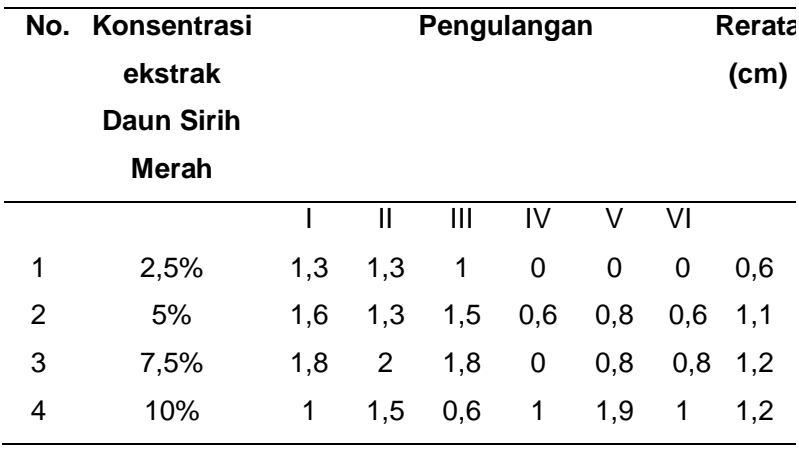

Uji normalitas pada data ekstrak daun sirih merah (Piper rocatum) didapatkan nilai $p>0,05$ sehingga dapat disimpulkan bahwa data terdistribusi normal, sehingga dilanjutkan dengan uji korelasi Pearson.

Korelasi antara konsentrasi ekstrak dengan daya hambat berhubungan positif sebesar 0,854 menunjukkan hubungan yang sangat kuat. Pada interpretasi didapatkan sebesar 0,146 ( $p>0,05)$, maka tidak ada korelasi yang signifikan.

Uji korelasi pada ekstrak daun dirih hijau (Piper betle L.) tidak dapat diproses dengan uji statistik dikarenakan hasil yang didapatkan adalah nol pada semua pengukuran yang dilakukan.

\section{PEMBAHASAN}

Daun sirih hijau (Piper betle L.) dan daun sirih merah (Piper crocatum Ruiz \& Pav) merupakan tanaman obat yang dipercaya masyarakat Indonesia memiliki khasiat kesehatan. Daun sirih hijau (Piper betle $L$.) mengandung minyak atsiri dengan $30 \%$ fenol dan beberapa derivatnya yang sebagian besar terdiri dari Chavicol paraallyphenol turunan dari Chavica betel.Isomer Euganol allypyrocatechine, Cineol methil euganol dan Caryophyllen, kavikol, kavibekol, estragol, terpinen. Senyawa tersebut merupakan turunan dari senyawa fenol yang memiliki sifat antibakteri lima kali lipat dari senyawa fenol biasa. Mekanisme fenol sebagai agen antibakteri adalah sebagai toksin dalam protoplasma, merusak dan menembus dinding serta mengendapkan protein sel bakteri. Senyawa fenolik bermolekul besar mampu menginaktifkan enzim essensial di dalam sel bakteri meskipun dalam konsentrasi yang sangat rendah.

Hasil dari uji statistik menunjukkan pada daun sirih merah (Piper crocatum Ruiz \& Pav) terdapat hubungan yang sangat kuat $(r=0,854)$ antara konsentrasi ekstrak dengan daya hambat, tetapi korelasinya tidak signifikan $(p>0,05)$. Pada daun sirih hijau (Piper betle L.) tidak dapat dilakukan uji statistik dikarenakan hasil yang didapatkan adalah nol pada semua pengukuran yang dilakukan.

Hal tersebut mungkin salah satunya dipengaruhi oleh perbedaan kadar eugenol yang nyata dalam minyak atsiri dari daun sirih merah (10,1129\%) dandaunsirih hijau (3,7187\%). Eugenol masih merupakan turunan senyawa flavanoid yang bersifat antiseptik sehingga pada konsentrasi yang kecil ekstrak daun sirih hijau (Piper betle L.) tidak mampu memberikan efek daya hambat terhadap pertumbuhan Escherichia coli. Berdasarkan hasil pengukuran, data daya hambat ekstrak daun sirih hijau (Piper betle L.) didapatkan hasil nol.

\section{KESIMPULAN}

Ekstrak daun sirih merah (Piper crocatum) memiliki efek daya hambat yang lebih baik terhadap pertumbuhan Escherichia coli dibandingkan ekstrak daun sirih hijau (Piper betle L.).

Semakin tinggi konsentrasi ekstrak, maka daya hambat terhadap bakteri akan semakin besar.

\section{DAFTAR PUSTAKA}

1. Suliantari. Aktivitas antibakteri ekstrak sirih hijau (Piper betle I.) terhadap bakteri patogen pangan: Jurnal,Teknol,dan Industri Pangan. 2008;19(1):1-7.

2. Hermawan A. Pengaruh ekstrak daun sirih (piper betle I.) terhadap pertumbuhan Staphylococcus aureus dan Escherichia coli dengan metode difusi disk. Surabaya: Universitas Airlangga; 2007.

3. Rachmawaty, Farida. Manfaat sirih merah (piper crocatum) sebagai agen antibakterial terhadap bakteri gram positif dan gram negatif. Jurnal Kedokteran dan Kesehatan Indonesia. 2008;1(1):12-22. 
4. Reveny J. Daya Antimikroba Ekstrak dan Fraksi Daun Sirih Merah (Piper betle Linn.).Sumatra Utara: Jurnal IImu Dasar 2011;12(1): 6-12.

5. Sulistyani N. (diunduh 24 April 2012). Tersedia dari: URL: HYPERLINK http://repository.ipb.ac.id
6. Departemen Kesehatan. (diunduh 11 Mei 2012). Tersedia dari: URL: HYPERLINK http://www.depkes.go.id

7. Soekidjo. Metodologi Penelitian Kesehatan Edisi revisi. Jakarta: PT.Asdi Mahasastya; 2010 